\title{
PENGGUNAAN PROBIOTIK KOMBINASI Lactococcus lactis DAN Lactobacillus acidophilus SEBAGAI PENGGANTI ANTIBIOTIKA PADA AYAM PETELUR YANG DIINFEKSI escherichia coli TERHADAP ANALISIS USAHA
}

\author{
USE OF COMBINATION PROBIOTIC Lactococcus lactis AND Lactobacillus \\ acidophilus AS A SUBSTITUTE OF ANTIBIOTICS IN CHICKEN LAYER \\ INFECTED BY Escherichia coli ON BUSINESS ANALYSIS
}

\author{
Hana Cipka Pramuda Wardhani ${ }^{1}$, Widya Paramita Lokapirnasari ${ }^{2 *}$, Koesnoto \\ Soepranianondo ${ }^{2}$ \\ ${ }^{1}$ Program Studi Agribisnis Veteriner, Universitas Airlangga, Surabaya 60286, Indonesia \\ , ${ }^{2}$ Departemen Peternakan Veteriner, Universitas Airlangga, Surabaya, 60286, Indonesia \\ *Email: widyaparamitalokapirnasari@gmail.com \\ (Diterima 06-03-2019; Disetujui 18 Juli 2019)
}

\begin{abstract}
ABSTRAK
Eschericia coli merupakan flora normal pada pencernaan ayam petelur yang bersifat non patogen, yang mampu berubah menjadi patogen dan menyebabkan ayam petelur mengalami penurunan produksi telur. Sehingga pemberian probiotik kombinasi Lactococcus lactis dan Lactobacillus acidophilus diharapkan mampu mengatasi $E$. coli serta menjadi pengganti antibiotika (Virginiamycin) dalam pakan ternak. Penelitian ini bertujuan untuk mengetahui analisis usaha meliputi Break Even Point (BEP), Revenue Cost Ratio (R/C Ratio), Payback Period (PP) dan Return on Invesment (ROI). Hasil terbaik yang diperoleh untuk penghitungan Break Even Point (BEP) pada perlakuan a0b2 dengan BEP harga Rp 15.695 dengan BEP produksi $21 \mathrm{~kg}$, Revenue Cost Ratio (R/C Ratio) menghasilkan nilai sebesar 1,217 untuk perlakuan a0b2, Payback Period (PP) menghasilkan nilai sebesar 1 tahun 3 bulan 9 hari, dan Return on Invesment (ROI) menghasilkan nilai sebesar 2,8. Disimpulkan bahwa perlakuan a0b2 memiliki hasil bagus untuk dikembangkan.
\end{abstract}

Kata kunci: Eschericia coli, Lactococcus lactis, Lactobacillus acidophilus, Analisis usaha

\begin{abstract}
Escherichia coli is a normal flora in the digestive system of laying hens that are non-pathogenic, which can change into pathogens and cause the egg production to decrease. So the combination of Lactococcus lactis and Lactobacillus acidophilus probiotics is expected to be able to overcome E. coli and become a substitute for the antibiotics (Virginiamycin) in animal feed. This study aims to determine business analysis including Break Event Points (BEP), Revenue Cost Ratio ( $R$ / C Ratio), Payback Period (PP) and Return On Investment (ROI). The best results obtained for the calculation of Break Event Point (BEP) on a0b2 treatment with a BEP of Rp. 17,587,24 with BEP production on alb2 of 14,36 kg, Revenue Cost Ratio (R / C Ratio) generates a value of 1,543 for treatment a0b2, Payback Period (PP) generates a value of 1 year 3 months 9 days and Return On Investment (ROI) generates a value of 3. It was concluded that the a0b2 treatment had good results to be developed.
\end{abstract}

Keywords: Eschericia coli, Lactococcus lactis, Lactobacillus acidophilus, Business Analysis

\section{PENDAHULUAN}

Kebutuhan protein hewani yang terdapat pada daging ayam dan telur membuat ayam banyak digemari karena harganya yang masih terjangkau untuk masyarakat. Meningkatnya permintaan telur mengakibatkan peternak memilih jalan keluar untuk memberikan 
antibiotika yang dicampur pada pakan yang berujuan untuk mempercepat pertumbuhan dan tidak mudah sakit. Kerugian karena bakteri patogen sering menyebabkan produksi telur menurun, sehingga peternak lebih sering memberikan antibiotika (Jamin, dkk., 2015). Efek pemberian antibiotika menyebabkan residu yang mengendap pada organ ayam yang mengakibatkan resistensi antibiotika tertentu pada ternak dan bahkan pada konsumen (Barton, 2000).

Pemberian probiotik diharap mampu menggantikan peran antibiotika. Probiotik merupakan makanan tambahan berupa sel-sel mikroba hidup yang memiliki pengaruh menguntungkan bagi inang serta manusia yang akan mengkonsumsinya (Supriatna, dkk, 2016). Probiotik mampu meningkatkan kecernaan ternak sehingga ternak mampu menyerap nutrisi pada pakan secara optimal, sehingga kebutuhan produksi terpenuhi dan kebutuhan tubuh juga terpenuhi (Subekti dan Hastuti, 2015).

Probiotik yang digunakan adalah Lactococcus lactis yang mampu menghasilkan asam laktat lebih cepat dibandingkan dengan bateri asam laktat lainnya yang bertugas menekan pertubuhan bakteri patogen seperti Escherichia coli (Nuryhev et al, 2016).
Lactobacillus acidophilus merupakan salah satu bahan campuran untuk pembuatan produk fermentasi yang baik untuk kesehatan saluran pencernaan, dan juga rongga mulut. Lactobacillus acidophilus juga mampu meningkatkan manfaat karbohidrat (Pertami dkk, 2013).

\section{METODE PENELITIAN}

Sampel yang digunakan dalam penelitian ini adalah 120 ekor ayam petelur dari salah satu peternakan di desa Talun Kecamatan Montong Kabupaten Tuban, dikumpulkan dari November 2018 - Desember 2018. Data yang diperoleh pada hari terakhir penelitian diolah menggunakan Microsoft Excel kemudian dilanjutkan dengan analisis statistik menggunakan Analysis of Variance (ANOVA) untuk mengetahui apakah terdapat perbedaan nyata pada perlakuan $(\mathrm{P}<0,05)$ dan sangat nyata ( $\mathrm{P}<0,01)$, lalu dilanjutkan dengan $\mathrm{Uji}$ Jarak Berganda Duncan. Alat yang digunakan dalam penelitian ini adalah timbangan digital dengan kapasitas $5 \mathrm{~kg}$ dengan ketelitian $0,01 \mathrm{~kg}$, termometer ruangan, hygrometer, kandang battery, tempat pakan, tempat minum dan penampung telur. Bahan penelitian antibiotika (Virginiamycin) probiotik Lactococcus lactis, Probiotik Lactobacillus acidophilus, desinfektan 
benzalkonium chloride 10\%, air bebas

chlorine, hewan coba ayam petelur umur
23 minggu pakan pabrik (tanpa antibiotika), dan bakateri E. coli.

Tabel 1. Pembagian Kelompok dengan Faktorial

Escherichia

coli

\begin{tabular}{|c|c|c|c|c|}
\hline \multirow{3}{*}{$\begin{array}{c}\text { Faktor } 1 \\
\text { (a) }\end{array}$} & & $\begin{array}{c}\text { Kontrol } \\
\text { (b0) }\end{array}$ & $\begin{array}{c}\text { Antibiotika } \\
\text { (b1) }\end{array}$ & $\begin{array}{c}\text { Probiotik Lactococcus lactis } \\
\mathbf{0 , 5} \% \text { Lactobacillus } \\
\text { acidophilus } 0,5 \% \text { (b2) }\end{array}$ \\
\hline & Tidak (a0) & $\mathrm{a} 0 \mathrm{~b} 0$ & $\mathrm{a} 0 \mathrm{~b} 1$ & $\mathrm{a} 0 \mathrm{~b} 2$ \\
\hline & Infeksi (a1) & alb0 & alb1 & $\mathrm{a} 1 \mathrm{~b} 2$ \\
\hline
\end{tabular}

Keterangan:

a0b0 : Kontrol tidak diinfeksi E. coli

alb0 : Kontrol diinfeksi E. coli

a0b1 : $0,1 \%$ dari berat pakan antibiotika Virginiamycin

alb1 : 0,1\% dari berat pakan antibiotika Virginiamycin + infeksi E. coli

a0b2 : 0,5\% dari konsumsi pakan Lactococcus lactis dan $0.5 \%$ dari konsumsi pakan Lactobacillus acidophilus

a1b2 : 0,5\% dari konsumsi pakan Lactococcus lactis dan $0.5 \%$ dari konsumsi pakan Lactobacillus acidophilus + infeksi E. coli

\section{Persiapan Infeksi Escherichia coli}

Dosis bakteri E. coli $10^{8} \mathrm{CFU} / \mathrm{ml}$ spesifik Avian Pathogenic Eschericihia Coli (APEC). Diberikan kepada 3 perlakuan infeksi masing-masing 20 ekor, secara oral pada perlakuan alb0, alb1 dan alb2.

\section{Persiapan Pencampuran Antibiotika}

Penimbangan pakan per minggu untuk perlakuan a0b1 dan alb1 masingmasing 20 ekor ayam petelur. Dosis antibiotika (Virginiamycin) yang diberikan $1 \%$ dari berat pakan. Diperoleh $12 \mathrm{~g} / 5 \mathrm{~kg}$ pakan /minggu. Dicampur hingga homogen.

\section{Persiapan Pencampuran Probiotik}

Pemberian probiotik setiap hari untuk perlakuan P3 dan P4 masingmasing 20 ekor ayam petelur. Dosis probiotik 0,5\% Lactococcus lactis dari konsumsi pakan dan 0,5\% Lactobacillus acidophilus dari konsumsi pakan $10^{7}$ $\mathrm{CFU} / \mathrm{g}$ dicampur dengan $180 \mathrm{ml} /$ ekor/hari.

\section{HASIL DAN PEMBAHASAN}

\section{Break Even Point (BEP)}

Break Even Point adalah cara untuk menentukan dan mencari jumlah barang yang harus dijual kepada konsumen dengan tujuan menutupi biaya-biaya yang timbul dan mendapat keuntungan. 
PENGGUNAAN PROBIOTIK KOMBINASI Lactococcus lactis DAN Lactobacillus acidophilus SEBAGAI PENGGANTI ANTIBIOTIKA PADA AYAM PETELUR YANG DIINFEKSI escherichia coli TERHADAP ANALISIS USAHA

Hana Cipka Pramuda Wardhani, Widya Paramita Lokapirnasari, Koesnoto Soepranianondo

$$
\text { BEP Harga }=\frac{\text { Total Biaya }}{\text { Harga Penjualan }} \text { BEP Produksi }=\frac{\text { Total Biaya }}{\text { Total Produksi }}
$$

Hasil tiap perlakuan BEP Harga: Hasil tiap perlakuan BEP Produksi:

$$
\begin{aligned}
& \text { a0b0 : Rp 19.312,34 a0b0 : 13,93 kg } \\
& \text { a1b0 : Rp 23.946,53 a1b0 : 13,94 kg } \\
& \text { a0b1 : Rp 18.481,85 a0b1 : 14,12 kg } \\
& \text { alb1 : Rp 20.731,18 alb1 : 14,11 kg } \\
& \text { a0b2 : Rp 17.587,24 a0b2 : 14,26 kg } \\
& \text { a1b2 : Rp 18.203,09 a1b2 : 14,36 kg }
\end{aligned}
$$

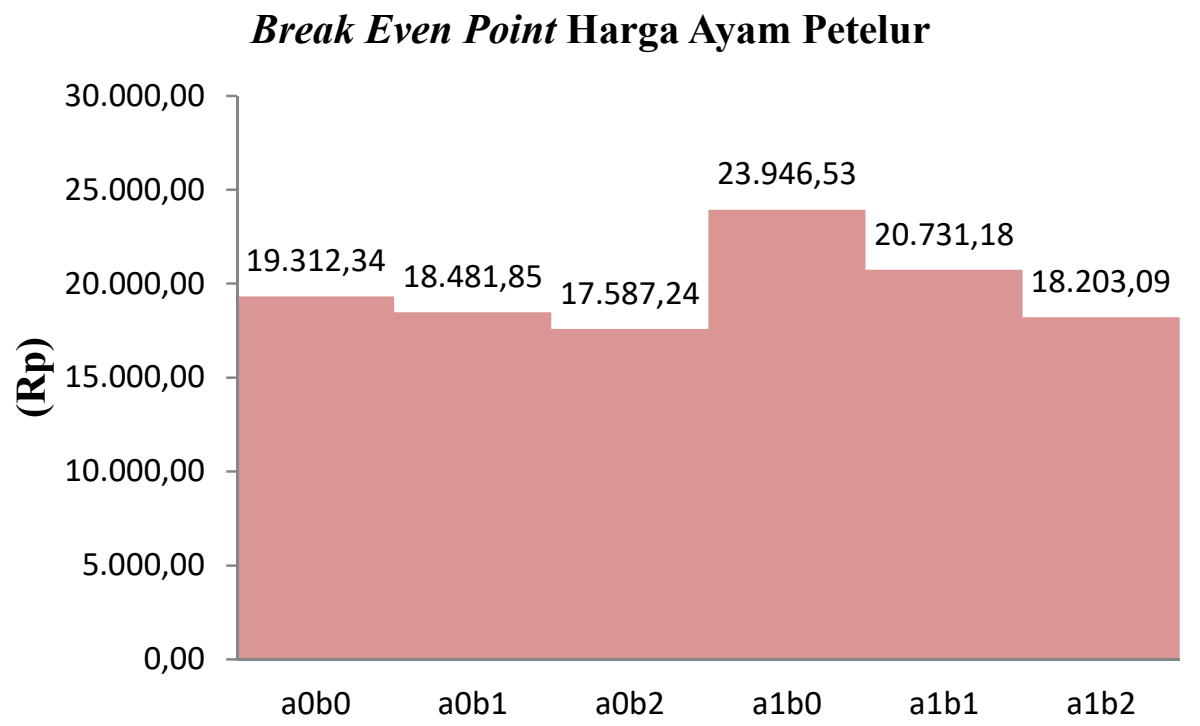

Break Even Point Produksi Ayam Petelur

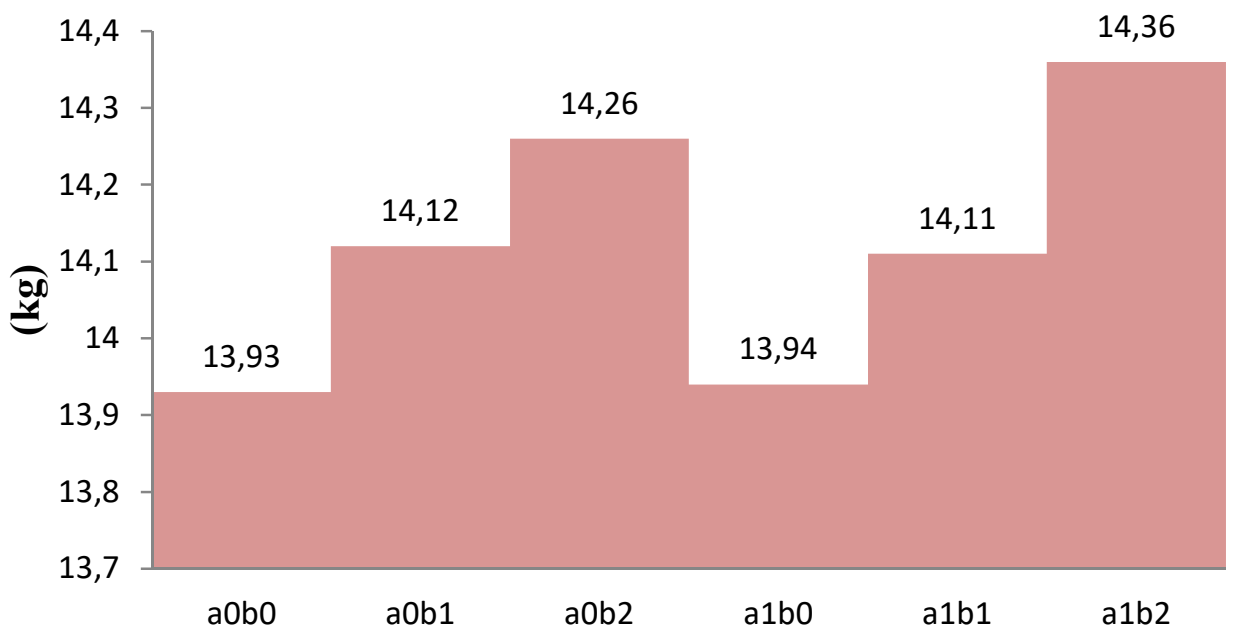


Gambar di atas menunjukkan bahwa perlakuan a0b2 memiliki hasil yang bagus yaitu BEP Harga Rp 17.587,24 dengan BEP Produksi 14,26 $\mathrm{kg}$.

$$
\mathrm{R} / \mathrm{C}=\frac{\text { Total penerimaan penjualan produk }}{\text { Total biaya }}
$$

Hasil tiap perlakuan :

$$
\begin{aligned}
& \text { a0b0 }: 1,412 \\
& \text { a0b1 }: 1,471 \\
& \text { a0b2 }: 1,543
\end{aligned}
$$$$
\text { alb0 : } 1,139
$$$$
\text { a1b1 : 1,312 }
$$$$
\text { a1b2 : } 1,489
$$

\section{Revenue Cost Ratio Ayam Petelur}

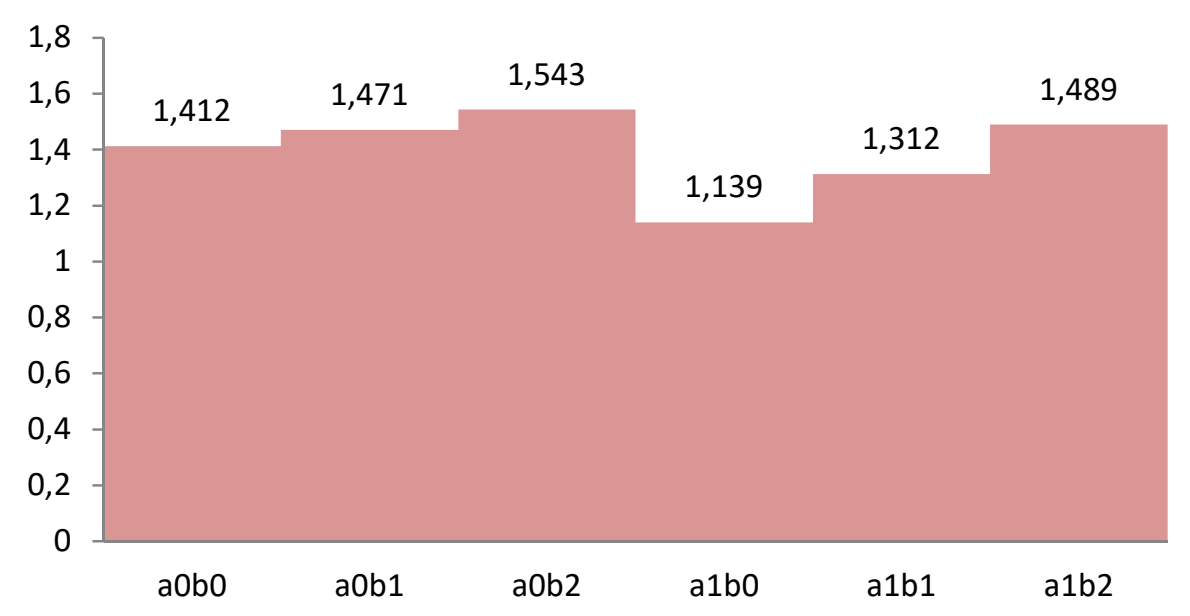

Gambar di atas menunjukkan bahwa perlakuan a0b2 memiliki hasil yang bagus yaitu 1,543 bahwa nilai yang diperoleh $>1$ maka usaha tersebut layak dikembangkan.

\section{Payback Period (PP)}

Payback Period adalah perhitungan antara pendapatan yang diperoleh antara selisih penerimaan dengan pengeluaran per tahun. Jika nilai yang diperoleh menunjukkan hasil yang lebih sedikit maka hasilnya semakin baik (Riyanto, 2016).

$$
\mathrm{PP}=\frac{\text { Investasi }}{\text { Cashflow } 1 \text { tahun }}
$$


PENGGUNAAN PROBIOTIK KOMBINASI Lactococcus lactis DAN Lactobacillus acidophilus SEBAGAI PENGGANTI ANTIBIOTIKA PADA AYAM PETELUR YANG DIINFEKSI escherichia coli TERHADAP ANALISIS USAHA

Hana Cipka Pramuda Wardhani, Widya Paramita Lokapirnasari, Koesnoto Soepranianondo

a0b0 : 1 year 8 months 7 days a1b0 : 5 years 5 months 5 days

a0b1 : 1 year 6 months 1 day

alb1 : 2 years 4 months 3 days

a0b2 : 1 year 3 months 9 days

a1b2 : 1 year 6 months 3 days

\section{Payback Period Ayam Petelur}

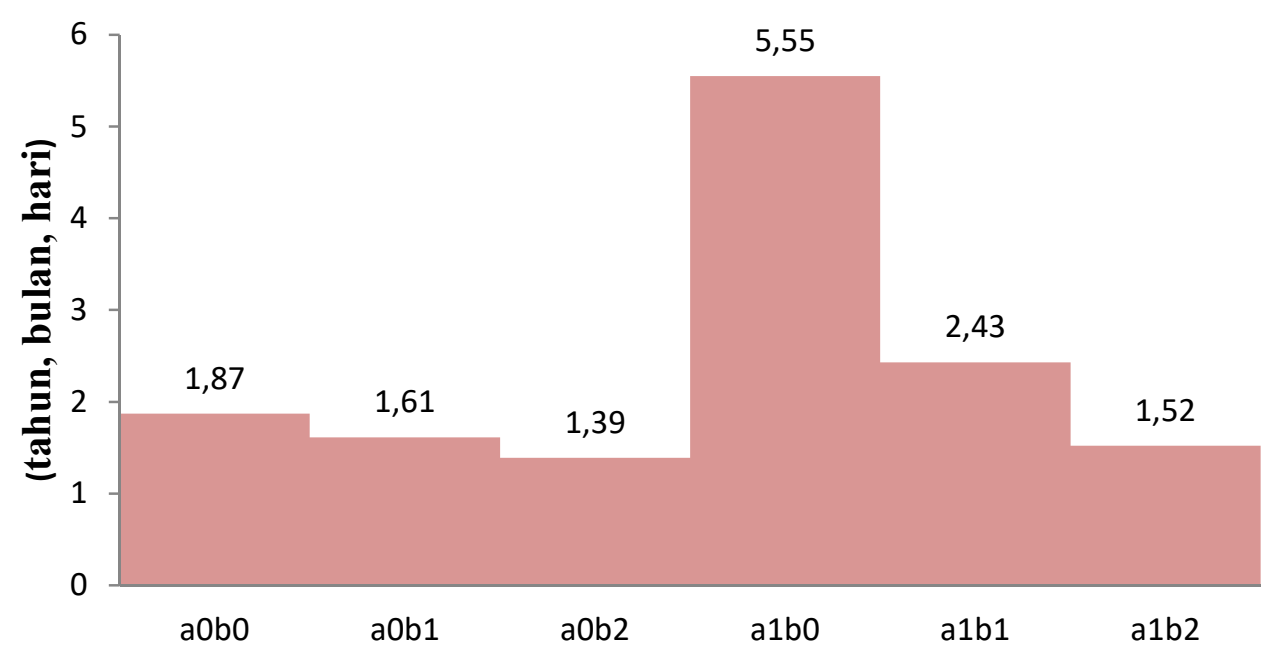

Gambar di atas menunjukkan bahwa perlakuan a0b2 memiliki hasil yang bagus yaitu $1,39=1$ tahun 3 bulan 9 hari. Perhitungan menggunakan bulan/15hari infeksi. Hasil semakin sedikit maka usaha tersebut layak dikembangkan.

\section{Return on Invesment (ROI)}

Return On Invesment adalah perhitungan untuk mengukur kemampuan perusahaan secara keseluruhan dalam menghasilkan keuntungan, serta dijadikan sebagai tolak ukur efektifitas sebuah manajemen dalam mengelola investas (Soepranianondo dkk, 2013).

$$
\text { ROI }=\frac{\text { Keuntungan bersih }}{\text { Modal usaha }} \times 100 \%
$$

\begin{tabular}{|c|c|}
\hline $\mathrm{a} 0 \mathrm{~b} 0: 2,2$ & alb0 \\
\hline $\mathrm{a} 0 \mathrm{~b} 1: 2,6$ & alb1 \\
\hline a0b2 : 3 & alb2 \\
\hline
\end{tabular}




\section{Return on Invesment Ayam Petelur}

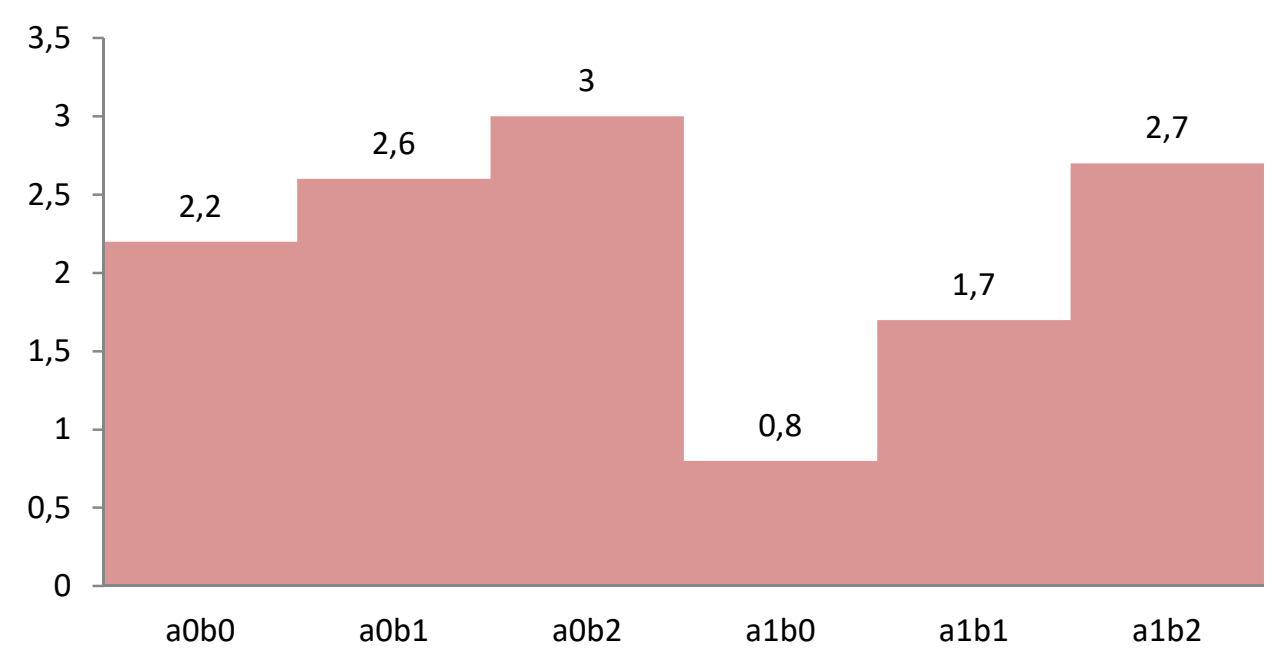

Gambar di atas menunjukkan bahwa perlakuan a0b1 dan a0b2 memiliki hasil yang bagus yaitu 2,8\%. Hasil yang diperoleh semakin tinggi maka semakin bagus.

Berdasarkan hasil penelitian yang dilakukan di Tuban menggunakan sampel ayam petelur dengan mengamati produksi telur dan konsumsi pakan setiap hari selama satu bulan. Analisis usaha mendapatkan hasil yaitu dalam penghitungan Break Even Point, Revenue Cost Ratio, Payback Period dan Return on Invesment. Penghitungan analisis usaha menunjukkan hasil yang bagus pada perlakuan a0b2 (tanpa infeksi + diberi probiotik). Penelitian ini menunjukkan bahwa perlakuan yang diberikan probiotik mampu menjaga produksi telur stabil dan mampu menekan pertumbuhan bakteri penghambat dalam pencernaan sehingga telur yang diproduksi berkualitas baik (Hassan et al, 2012).

Peternakan ayam petelur merupakan usaha yang berkembang beberapa tahun terakhir, karena meningkatnya permintaan telur ayam sebagai bahan baku pangan untuk kebutuhan masyarakat. Kita tahu protein hewani merupakan protein yang dibutuhkan oleh tubuh salah satunya yaitu terdapat pada telur ayam, sehingga telur ayam lebih diminati karena harga yang terjangkau (Setiawan dkk, 2016).

Eschericia coli adalah flora normal pada saluran pencernaan ayam petelur yang bersifat nonpatogen, tetapi bisa berubah menjadi patogen apabila ayam petelur tersebut mengalami penurunan imun sehingga mengakibatkan ternak mengalami penurunan produksi telur 
PENGGUNAAN PROBIOTIK KOMBINASI Lactococcus lactis DAN Lactobacillus acidophilus SEBAGAI

PENGGANTI ANTIBIOTIKA PADA AYAM PETELUR YANG DIINFEKSI escherichia coli TERHADAP ANALISIS USAHA

Hana Cipka Pramuda Wardhani, Widya Paramita Lokapirnasari, Koesnoto Soepranianondo

(Arifin dan Pramono, 2014). Penurunan produksi telur mengakibatkan performan ayam petelur buruk, sehingga peternak mengalami kerugian. E. coli dapat ditekan pertumbuhannya dengan pemberian antibiotika pada pakan, akan tetapi penggunaan antibiotika jangka panjang sudah dilarang pemberiannya pada pakan ayam dikarenakan residu pada hasil ternak yang berdampak buruk untuk konsumen (Suryani dkk, 2014).

Probiotik merupakan alternatif yang dapat dipilih sebagai pengganti antibiotika pada pakan, pemberian probiotik dapat diberikan melalui pakan dan minum. Probiotik kombinasi yang digunakan adalah Lactococcus lactis dan Lactobacillus acidophilus merupakan probiotik yang baik untuk pencernaan dan mampu meningkatkan daya serap sehingga nutrisi yang diperolah dari pakan mampu terserap sempurna (Enby et al, 2012). Penyerapan yang sempurna mampu meningkatkan sistem imun sehingga ayam petelur tidak mudah sakit akibat bakteri patogen. Probiotik mampu sebagai pengatur keseimbangan mikroorganisme pada saluran pencernaan dan memiliki sifat tidak patogen sehingga aman untuk dikonsumsi ayam petelur jangka panjang (Garabal et al, 2007).

Penelitian ini dilakukan karena pemakaian antibiotika pada pakan sebagai tambahan untuk kesehatan ternak berdampak buruk untuk kesehatan konsumen, menyebabkan efek seperti mual dan bahkan resisten terhadap antibiotika tertentu. Hal ini bisa terjadi karena pemberian antibiotika pada pakan tidak diawasi oleh dokter hewan, sehingga pemberiannya tidak sesuai dosis. Kejadian ini menyebabkan saya melakukan eksperimen pemberian probiotik kombinasi Lactococcus lactis dan Lactobacillus acidophilus sebagai pengganti antibiotika. Peran probiotik sendiri hampir sama dengan antibiotika yaitu menekan pertumbuhan bakteri patogen seperti Eschericia coli. Keunggulan probiotik mampu menjaga kesehatan pencernaan dan mampu meningkatkan penyerapan nutrisi sehingga kebutuhan produksi dan kebutuhan tubuh terpenuhi. Menjadikan peternak lebih efisien dalam pemberian pakan dan produksi telur stabil, mengakibatkan keuntungan yang lebih dan menyehatkan konsumen.

\section{KESIMPULAN}

Penambahan probiotik kombinasi Lactococcus lactis dan Lactobacillus acidophilus melalui air minum pada analisis usaha dapat menurunkan Break Even Point harga, meningkatkan Break Event Point produksi, meningkatkan 
Revenue Cost Ratio dan menurunkan Payback Period, serta mampu menggantikan peran antibiotika sebagai Antibiotic Growth Promoter (AGP) dan menjaga ayam petelur agar tidak mudah terinfeksi.

\section{DAFTAR PUSTAKA}

Arifin, M dan V.J Pramono. 2014. Pengaruh Pemberian Sinbiotik Sebagai Alternatif Pengganti Antibiotic Growth Promoter Terhadap Pertumbuhan dan Ukuran Vili Usus Ayam Broiler. Urnal Sain Veteriner. ISSN : 0126-0421.

Asnidar dan Asrida. 2017. Analisis Kelayakan Usaha Home Industry Kerupuk Opak Di Desa Paloh Meunasah Dayah Kecamatan Muara Satu Kabupaten Aceh Utara. Jurnal S. Pertanian 1(1): 39-47.

Barton, M.D. 2000. Antibiotic use in animal feed and its impact on human health. Nutr Res Rev. 13(2): 1-19.

Choiriyah, V.U., AR.. M.D dan R.R. Hidayat. Analisis Break Event Point Sebagai Alat Perencanaan Penjualan Pada Tingkat Laba yang Diharapkan. Jurnal Administrasi Bisnis 35(1).

Enby, H.M., Maher, A.H., Birte, S., Susanne, J and J.S. Dirk. 2012. Probiotic Lactobacillus acidophilus NCFM and Bifidobacterium animalis subsp lactis Bl-04 interactions with prebiotic carbohydrates using differential proteomics and protein characterization. Kgs. Lyngby: Technical University of Denmark (DTU).

Garabal, J.I., Alonso, P.R., and J.A. Centeno.2007. Characterization of lactic acid bacteria i o ed om w ow' mi $\mathrm{k}$ hee e currently produced in Galicia (NW Spain). Swiss Soc. of Food Sci. and Technol.

Hassan, E.R., Mahgoob, K.M., Zaenab, Kh.M.E., Girh, AM.S., and H.M. Mekky. 2012. Comparative Studies between the Effects of Antibiotic (Oxytetracycline); Probiotic and Acidifier on E. coli Infection and Immune Response in Broiler Chickens. Jurnal of American Science, 2012;8(4).

Jamin, F., Abrar, M., Dewi, M., Yanrivina, S.V.S., Fakhrurrazi., Manaf, Z.H., dan Syafruddin. 2015. Infeksi Escherichia coli Pada Anak Ayam Kampung (Gallus domesticus) di Pasar Lambaro Aceh Besar. Jurnal Medika Veterineria 9(1).

Nuryhev, M.Z., Stoyanova, L.G and A.I Netrosov. 2016. New Probiotic Culture of Lactococcus lactis ssp. Lactis: Effective Opportunities and Prospects. Jurnal of Microbial \& Biochemical Technology.

Pertami S.D., Pancasiyauar M., Irasari S.A., Rahardjo and M.B., Wasilah. 2013. Lactobacillus acidophilus Probiotic Inhibits the Growth of Candida albicans. Jurnal of Dentistry Indonesia 20(3): 64-67.

Riyanto B. 2011. Dasar-dasar Pembelajaran Perusahaan, BPFEYogyakarta. Yogyakarta.

Setiawan, T., Afnan, R., dan N. Ulupi. 2016. Performa Produksi dan Kualitas Telur Ayam Petelur pada Sistem Litter dan Dage dengan Suhu Kandang Berdeda. Fakultas Peternakan Institup Pertanian Bogor. Jurnal Ilmu Produksi dan Teknologi Hasil Peternakan 02(1): 197-203.

Soepranianondo, K., R. Sidik, D.S. Nazar, S. Hidanah, Pratisto dan S.H. Warsito. 2013. Buku Ajar Kewirausahaan. Airlangga 
PENGGUNAAN PROBIOTIK KOMBINASI Lactococcus lactis DAN Lactobacillus acidophilus SEBAGAI PENGGANTI ANTIBIOTIKA PADA AYAM PETELUR YANG DIINFEKSI escherichia coli TERHADAP ANALISIS USAHA

Hana Cipka Pramuda Wardhani, Widya Paramita Lokapirnasari, Koesnoto Soepranianondo

Univerity Press. Surabaya. 192197.

Subekti, E dan D. Hastuti. 2015. Pengaruh Penambahan Probiotik Herbal Pada Ransum Terhadap Performent Itik Pedaging. Program Studi Agribisnis Universitas Wahid Hasyim Semarang.

Supriatna, I., Hismayasari, I.B., Bidiadnyani, I.G.A., Sayuti, M., dan A. Yani. 2016. Analisis Karakteristik Bakteri Probiotik. Politeknik Kelautan dan Perikanan Sorong. Jurnal Airaha 5(2): 130132.
Suryani, A.E., Karimy, M.F., Istiqomah, L., Sofyan, A., Herdian, H., dan M.H. Wibowo. 2014. Prevalensi Kolibasilosis Pada Ayam Broiler Yang Diinfeksi Escherichia coli Dengan Pemberian Bioaditif, Probiotik dan Antibiotik. Laboratorium Mikrobiologi Fakultas Kedokteran Hewan Universitas Gadjah Mada. Bagian Pakan dan Nutrisi Ternak. Vol. 17. No. 2. 